\title{
Changes in Soil Nitrogen, Phosphorus, and Carbon Stocks in a Forest Ecosystem at Different Successional Stages in Leyte, Philippines
}

Anane R. Sereñina ${ }^{1 *}$ and Suzette B. Lina ${ }^{2}$

\section{ABSTRACT}

Forests play a vital role in the global carbon cycle since these are sources and sinks of carbon. This study was conducted to evaluate the changes in soil carbon stocks and some essential nutrients of different succession stages in two different soil types in Leyte Province. A space-fortime substitution approach was done in this study. Measurements of the physical, chemical, and biological properties of the soils were done following standard methods. The sites were characterized as Ultisol (Site 1 - Baybay, Leyte) and Andisol (Site 2 - Ormoc City). Results showed no significant differences among all the soil properties in the different forest succession stages in each site. However, variation in soil properties between sites was clearly observed. Site 2 had higher soil porosity and water holding capacity, but had lower bulk density than Site 1. Soils in Site 2 were more acidic, had higher total organic carbon, total $\mathrm{N}$, and $\mathrm{CEC}_{\mathrm{pot}}$, but had lower exchangeable bases and $\mathrm{CEC}_{\text {eff }}$ than in Site 1. Both sites had low available $\mathrm{P}$. The $\mathrm{C}: \mathrm{N}$ ratios in all forest successions were significantly lower in Site 1 than in Site 2. This conforms to the results of substrate-induced respiration, where Site 1 was more active in $\mathrm{CO}_{2}$ evolution than Site 2. Moreover, the soils in Site 2 significantly contained more SOC stocks (108$180 \mathrm{Mg} \mathrm{C}^{-1}$ ) than in Site 1 (49-76 Mg C ha'). However, SOC stocks did not vary significantly in both sites. This result implies that the determination of soil physico-chemical properties is important in evaluating the changes of C:N ratios as well as of SOC stocks. In this study, Andisols had higher potential in storing organic $\mathrm{C}$ than Ultisols.

Keywords: successional stages, soil physical and chemical properties, C:N, C stocks

${ }^{1}$ Mindoro State College of Agriculture and Technology, College of Agriculture and Allied Fields, Victoria, Oriental Mindoro, Philippines

${ }^{2}$ Visayas State University, Department of Soil Science, Visca, Baybay City, Leyte, Philippines 


\section{INTRODUCTION}

Environmental degradation is a global threat exacerbated by increasing global population. With a finite lowland area, people are forced to live and make a living in upland areas or in forested areas or covers. In such a situation, altering the upland environment could affect not only the macro and micro fauna and flora in the ecosystem, but also the carbon (C) stocks and other essential nutrients in the soil.

Forest covers constitute almost half of the total global land area and contain over $80 \%$ of terrestrial biodiversity. Furthermore, they play a crucial part in the economic and environmental aspects of communities within their range. This is because they provide essential goods and services such as basic needs (lumber, fuelwood, food, and medicine), carbon sequestration, soil and water conservation, nutrient cycling, and wildlife habitat preservation, especially in primary forest (Secretariat of the Convention on Biological Diversity 2001). However, there is a rapid decline in forest covers around the world especially in tropical regions (Meyfroidt \& Lambin 2011; Hansen et al 2013). Seasonal tropical forests are undergoing rapid conversion to agriculture, which substantially decreases soil carbon stocks (Allen et al 2003). It is expected that there is significant loss of soil carbon stocks from the primary forest to the lower forest successions due to changes in vegetation.

Soil carbon stocks in the tropics play a vital role in the global greenhouse gas balance and soil quality. However, substantial loss of carbon in the soil is inevitable due to rapid land use, high initial stocks, and high potential rates of decomposition. Furthermore, Dela Cruz (2010) pointed out that there are two major factors that affect soil carbon in a forest ecosystem in the Philippines: natural and anthropogenic. Natural factors include climate, topography, and natural disturbances while anthropogenic factors involve land use changes, land use, and management (Lasco et al 2007; Dela Cruz et al 2008; Dela Cruz 2010; Salang 2010). However, available data on carbon stocks in primary forests are limited due to high inaccessibility of areas and less emphasis on the effect of soil morpho-physicochemical properties in carbon stocks.

This study sought to determine the changes in soil carbon stocks and $\mathrm{C}: \mathrm{N}$ ratio as influenced by the different forest succession stages and the soil physico-chemical properties.

\section{MATERIALS AND METHODS}

\section{Site Description}

The study covered two cities in the province of Leyte, namely: Baybay City and Ormoc City (Figure 1) where the identified successional stages included the primary forest, secondary forest, and grassland. Baybay City 
and Ormoc City have three different soil orders: Inceptisols and Ultisols in Baybay City and Andisols in Ormoc City (Asio 1996).

The Baybay Site is located in Pangasugan, Baybay City, Leyte where a primary forest (Baybay Inceptisol PF), secondary forest (Baybay Ultisol SF), and grassland (Baybay Ultisol GL) were still intact and lay adjacent to each other. The forest areas were mostly composed of dipterocarp species while the GL was converted into coconut and abaca plantation. The PF Site, which was not disturbed by human activities, was located at the middle slope of a high gradient mountain. The area was steep with an elevation of 352 meters above sea level (asl). Rock outcrops were abundant and erosion was visible in the area. The vegetation was dominated by dipterocarp tree species such as white lauan (Shorea contorta), bagtikan (Parashorea malaanonan), malakawayan (Conocarpus lancifolius), and kaningag (Cinnamomum cebuense).

SF was located at the eastern part adjacent to PF, positioned at the middle slope of a volcanic hill. The area was situated on a very steep slope with an elevation of 177 meters asl and rock outcrops and erosion were noticeable. It was mainly dominated by dipterocarp species and other species, namely: rattan (Calamus deerratus), narra (Pterocarpus indicus), balikbikan (Mastixia pentandra Blume), and molave (Vitex parviflora). GL was located in the northeast part adjacent to SF, positioned at the middle slope of a volcanic hill with an elevation of 110 meters asl. The plant species found in the area were coconut (Cocos nucifera), abaca (Musa textilis), carabao grass (Paspalum conjugatum), ferns, and kudzu (Pueraria montana).

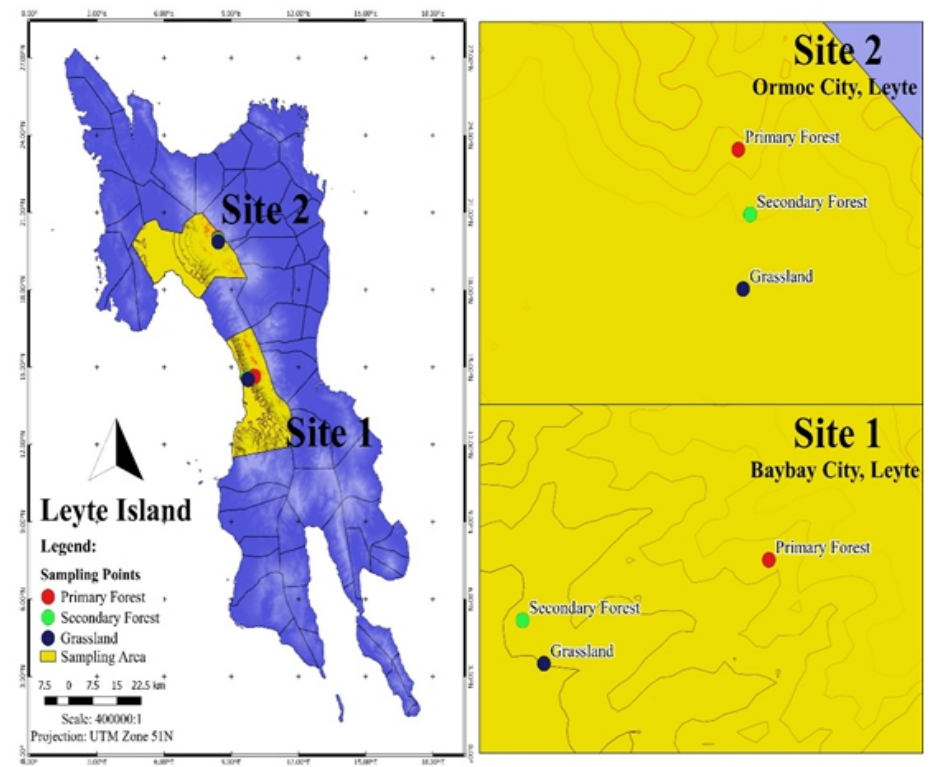

Figure 1. Location of the study Site in Ormoc City (Site 2) and Baybay City, Leyte (Site 1) 
The Ormoc Site was located in Cabintan, Ormoc City, where the primary forest (Ormoc Andisol PF), secondary forest (Ormoc Andisol SF), and grassland (Ormoc Andisol GL) were adjacent to each other. The primary and secondary forests were dominated by dipterocarp species and the grassland was planted with coconut. PF was located on the upper slope of a high and steep gradient mountain with an elevation of 992 meters asl. The vegetation was dominated by dipterocarp species such as tanguile (Shorea polysperma), guisok-guisok (Hopea philippinensis), and plants like pitcher plant (Nepenthes spp.). SF was located south of the PF, positioned at the middle slope of a high and steep gradient mountain with an elevation of 818 meters asl. The vegetation was dominated by dipterocarp species such as tanguile (Shorea polysperma), guisok-guisok (Hopea philippinensis), and plants like tree fern (Cyatheales spp.). Lastly, GL was located south of the SF, positioned at the middle slope of a high gradient mountain with an elevation of 652 meters asl. The dominant vegetation were carabao grass (Paspalum conjugatum), coconut (Cocos nucifera), mani-mani (Arachis pintoi), makahiya (Mimosa pudica), unod-unod (Cyperus rotundus), scorpion weed (Heliotropium indicum Linn.), and ferns. The climate in the two sites was classified as Type IV, characterized by rainfall that is more or less evenly distributed throughout the year (Coronas 1920). The soil temperature regime was isohyperthermic with an annual average temperature of $22^{\circ} \mathrm{C}$ and does not fluctuate above $5^{\circ} \mathrm{C}$. Soil moisture regime was udic, wherein water was available year-round (Soil Survey Staff 1999).

\section{Sampling Design}

A paired-area or space-for-time substitution approach was done in this study (Asio 1996; de Koning et al 2003; Veldkamp et al 2003; Paul et al 2008). This assumes that the two successional stages (e.g. secondary forest and grassland) originated from the adjacent primary forest. They were selected carefully to have comparable soil physical and chemical properties, climate, parent material, and changes in soil properties, especially the soil carbon stocks.

\section{Profile Description and Soil Sample Collection and Preparation}

After site selection, a pit measuring approximately $1 \mathrm{~m} \times 1 \mathrm{~m}$ with a depth of at least $1 \mathrm{~m}$ was dug manually in the primary forest, secondary forest, and grassland. This served as the representative soil profile. The soil horizon was used as basic sampling unit and its boundaries were determined for proper characterization. In each soil horizon, three continuous and uniform slices from the uppermost boundary down to the lowest part were collected, mixed, and composited in accordance to the quantitative sampling method of Schlichting et al (1995). Approximately 1 
$\mathrm{kg}$ of soil was collected from each soil horizon and placed in properly labeled plastic bags. Soil samples collected from each soil profile were used for determining soil physico-chemical properties. Site description, which covers biophysical characteristics, was done following the FAO Guidelines for Soil Description (Jahn et al 2006) and geographical coordinates using GPS was determined in the field (Table 1).

A stratified random sampling scheme was carried out in choosing the sub-sampling points for composite soil collection. Soil samples from stratified random sampling were used in determining SOC stocks, C:N ratio and substrate induced respiration. In each Site of the successional stage, three plots measuring $5 \mathrm{~m} \times 5 \mathrm{~m}$ were randomly established as replications. In each plot, five sub-sampling points were randomly established at approximately $5 \mathrm{~m}$ from each other. Soil samples in each of the subsampling points were collected uniformly from a depth of $0-20 \mathrm{~cm}$. Immediately after sampling, the soil samples were placed in properly labeled plastic bags and brought to the Department of Soil Science, VSU, Visca, Baybay City, Leyte for drying and analyses. Samples were air-dried and pulverized using a wooden mallet and sieved in a 2-mm wire mesh to get the fine earth for the determination of most of the soils' physical and chemical properties. For organic matter and nitrogen determination, soil samples were further ground and allowed to pass through a $0.425-\mathrm{mm}$ wire mesh.

\section{Laboratory Analysis}

Particle size distribution was determined using Pipette method (ISRIC 1995). Bulk density was analyzed using the core method (PCARR 1980) and percent (\%) porosity was calculated from the bulk density value and a constant particle density of $2.65 \mathrm{~g} / \mathrm{cm}^{3}$. Water holding capacity and field capacity were also determined using the Gravimetric Method (Klute 1986).

Soil $\mathrm{pH}\left(\mathrm{H}_{2} \mathrm{O}\right.$ and $\left.0.01 \mathrm{M} \mathrm{KCl}\right)$ was analyzed by potentiometric method using a soil-water/solution ratio of 1:2.5 (ISRIC 1995). Exchangeable Acidity $\left(\mathrm{Al}^{+}\right.$and $\left.\mathrm{H}^{+}\right)$was analyzed using $1 \mathrm{~N} \mathrm{KCl}$ as extractant and quantified by titrating the resulting extract with $0.1 \mathrm{~N} \mathrm{NaOH}$ (Thomas 1982). Soil organic carbon was analyzed following the Heanes' method (Heanes 1984). Total nitrogen was determined colorimetrically by the salicylatehypochlorite method of Baethgen and Alley (1989). Available P was done according to Bray 2 (ISRIC 2002). Exchangeable Bases ( $\mathrm{Ca}, \mathrm{Mg}, \mathrm{Na}$, and $\mathrm{K}$ ) and the Cation Exchange Capacity (potential CEC) were extracted using the $1 \mathrm{~N} \mathrm{NH}_{4} \mathrm{OAc}(\mathrm{pH} 7.0)$ method (ISRIC 1995). Extracted Ca, Mg, Na, and K were analyzed using the DTPA - Atomic Absorption Spectroscopy method (Reed \& Martens 1996). Effective Cation Exchange Capacity (cmolc kg-1) was calculated by summing up the amount of the exchangeable bases $(\mathrm{K}, \mathrm{Mg}$, $\mathrm{Ca}$, and $\mathrm{Na}$ ) and total acidity $\left(\mathrm{Al}^{3+}\right.$ and $\mathrm{H}+$ ). The microbial analysis was done through substrate-induced respiration (SIR). 


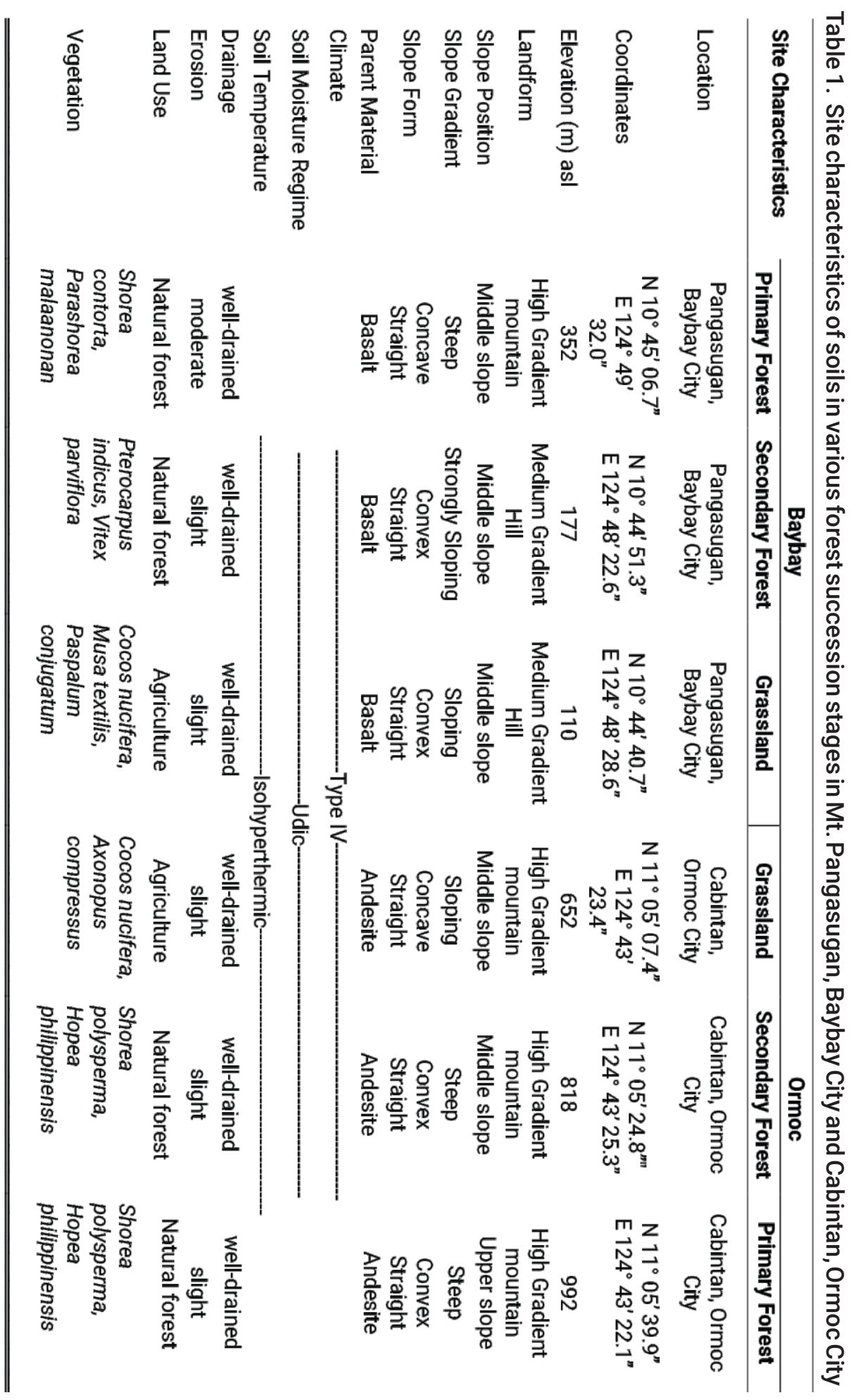




\section{Data Analysis}

Depth function of each soil property was plotted. The values determined for each property were compared with the ranges in Landon (1991) to determine if they would indicate low, moderate, or high levels. Soil properties from each composite site were computed for analysis of variance (ANOVA) using the Statistical Tool for Agricultural Research (STAR) v. 2.0.1. If found significant, the means of composite samples were compared using Least Significant Difference (LSD) test at $5 \%$ level of significance.

\section{RESULTS AND DISCUSSION}

\section{Site Morphological and Physical Characteristics}

Soil horizonation varied from Ah-AC-C1-C2, Ah-AB-Bt1-Bt2-BC, and ApBt1-Bt2-BC1-BC2 in Baybay Inceptisol PF, Baybay Ultisol SF, and Baybay Ultisol GL, respectively, and Ap-Bw1-Bw2-Bw3-BC, Ah-Bw1-Bw2-Bw3 and Ah-Bw-BC-C in Ormoc Andisol GL, Ormoc Andisol SF, and Ormoc Andisol PF, respectively. Looking at the soil horizons, there was evident soil development among all the profiles; however, the Baybay Site was more developed than the Ormoc Site due to the presence of argillic horizon in profiles 2 and 3. Horizon A thickness varied from $28 \mathrm{~cm}$ in Baybay Inceptisol PF, $10 \mathrm{~cm}$ in Baybay Ultisol SF, $13 \mathrm{~cm}$ in Baybay Ultisol GL, $15 \mathrm{~cm}$ in Ormoc Andisol GL, and $23 \mathrm{~cm}$ in both profiles 5 and 6 . Undeveloped clays were found in soil profiles $1,4,5$, and 6 (Tables $2 \& 3$ ). In addition, the presence of saprolites in the subsurface horizons in all profiles indicated that partial weathering occurred in the area.

Soil color in all profiles in both sites was 10 YR yellowish brown. Baybay Inceptisol PF soil color ranged from 10 YR 4/2 and 10 YR 5/2 in surface horizons to 10 YR 5/6 in the subsurface horizons. Baybay Ultisol SF had 10 YR $3 / 3$ and 10 YR 5/3 in surface horizons and 10 YR 5/4 and 10 YR 7/2 in subsurface horizons. Baybay Ultisol GL's soil color differed from 10 YR 4/3 and 10 YR $5 / 3$ in surface horizons to 10 YR $6 / 4$ in subsurface horizons. Soil color in Ormoc Andisol GL ranged from 10 YR 5/2 to 10 YR 4/3 in surface horizons and 10YR 5/3 to 10 YR $6 / 3$ in subsurface horizons. Soil Ormoc Andisol SF's soil color ranged from 10 YR 3/4 and 10 YR 4/4 in surface horizons to 10 YR 5/4 to 10 YR 6/4 in subsurface horizons. Furthermore, Ormoc Andisol PF's soil color varied from 10 YR $3 / 3$ and 10 YR 5/3 in surface horizons to 10 YR 6/4 in subsurface horizons (Tables $2 \& 3$ ). 
Sereñina \& Lina

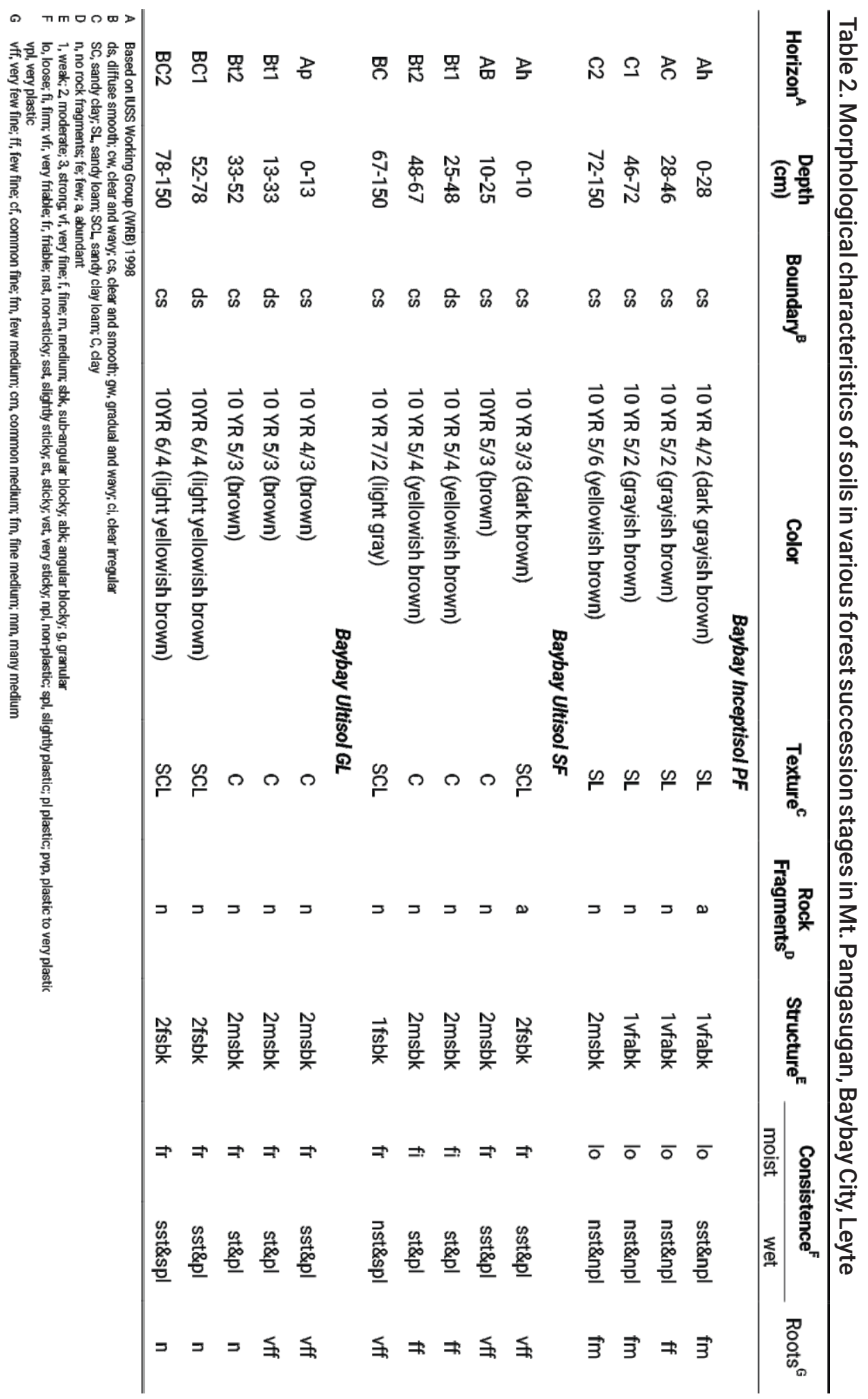


Changes in Soil Nitrogen, Phosphorus, and Carbon Stocks in a Forest Ecosystem

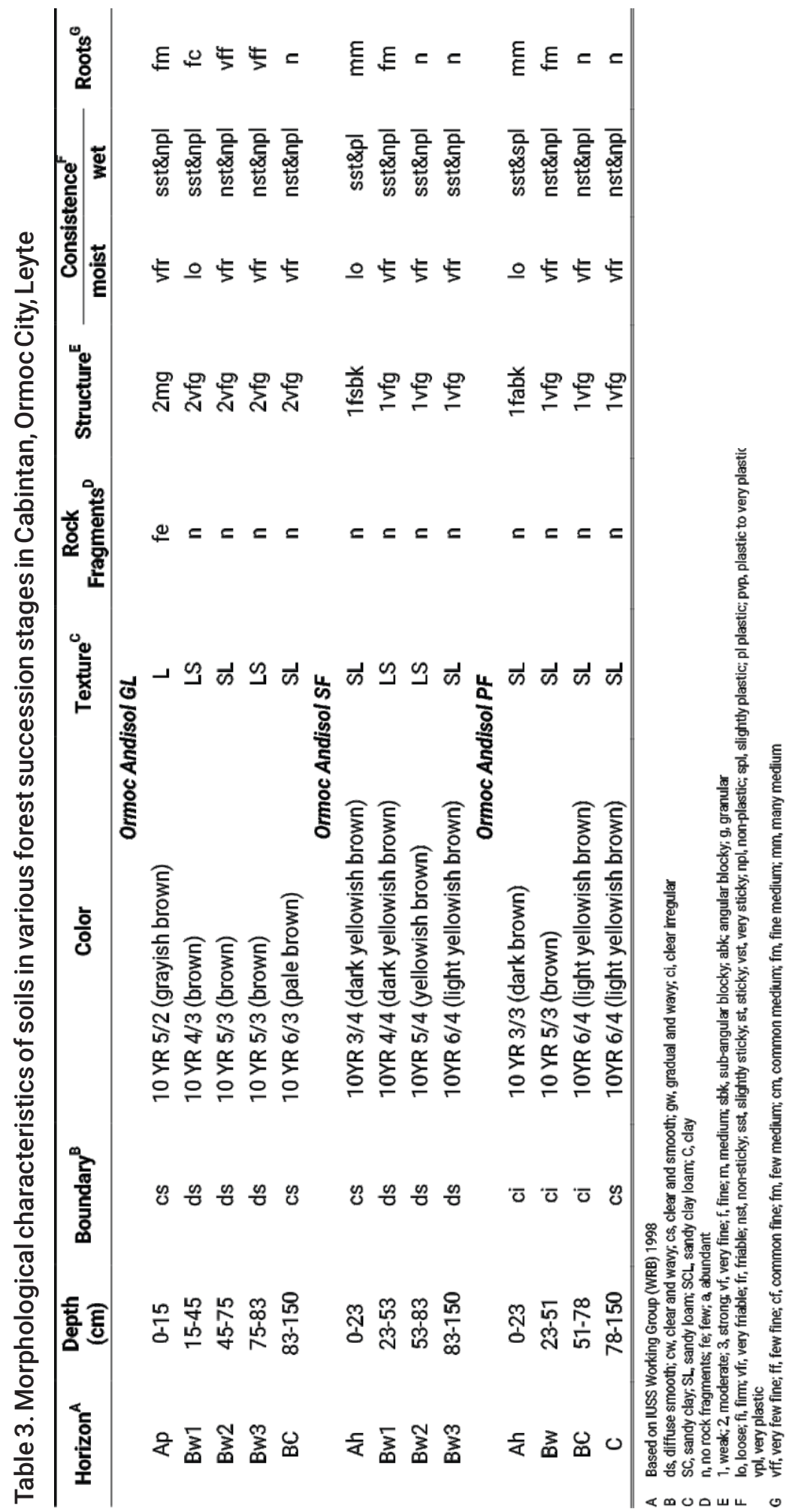




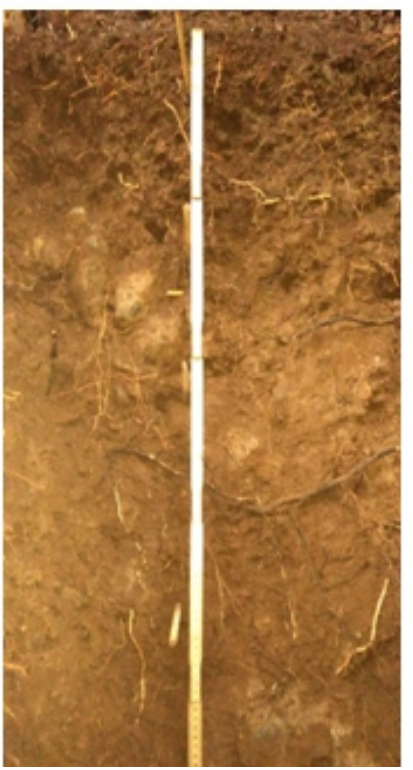

Baybay Inceptisol

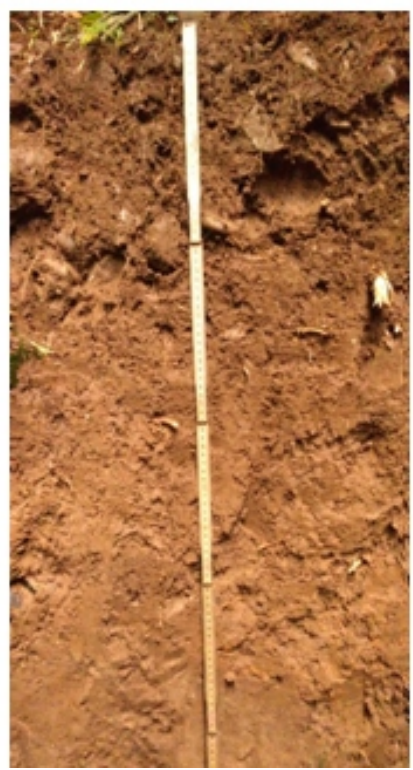

Baybay Ultisol SF

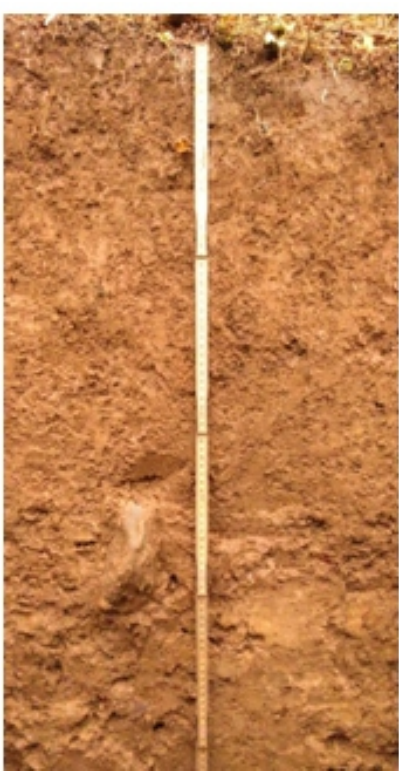

Baybay Ultisol GL

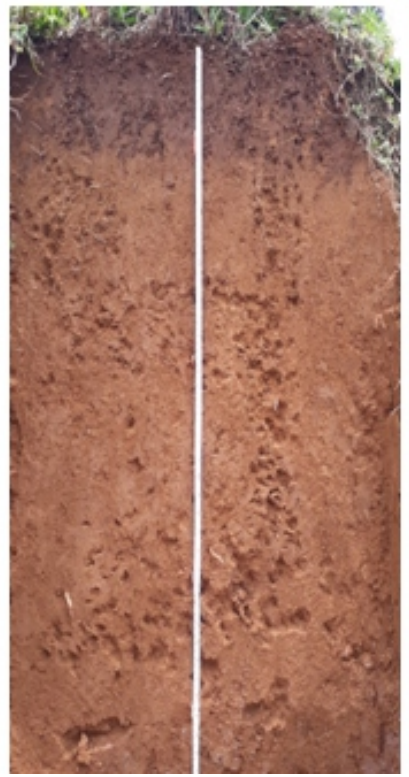

Ormoc Andisol GL

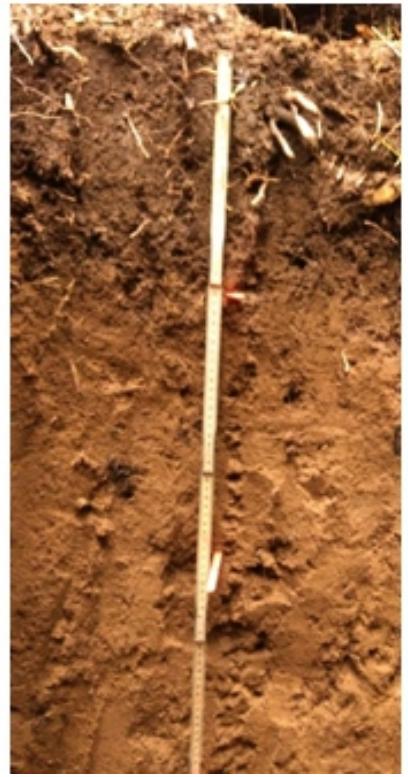

Ormoc Andisol SF

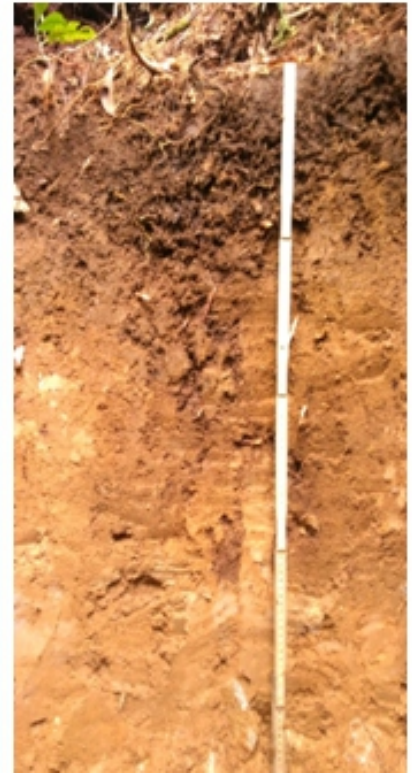

Ormoc Andisol PF

Figure 2. Soil profiles showing different forest successional stages of the sites in Baybay and Ormoc 
There was a difference in soil structure among the profiles between Site 1 and Site 2. In Site 1, Baybay Inceptisol PF had a structure that ranged from weak very fine sub-angular blocky to moderate medium sub-angular blocky. In Baybay Ultisol SF and Baybay Ultisol GL, the soil structure varied from moderate fine sub-angular blocky to moderate medium sub-angular blocky. While in Site 2, Ormoc Andisol GL had moderate medium granular to moderate very fine granular structure. Ormoc Andisol FS and Ormoc Andisol PF ranged from weak very fine sub-angular blocky structure to weak very fine granular structure. The moderate medium sub-angular blocky structure throughout the soil horizon is evidence of having high clay content in the profile. Soil consistency varied among soil profiles when wet due to differences in soil texture.

There were variations in soil consistency among the profiles in Site 1. In Baybay Inceptisol PF, soil throughout the profile was loose, non-sticky, and not plastic except in horizon A where it was slightly plastic. This could be due to high organic matter in the surface. While Baybay Ultisol SF and Baybay Ultisol GL were friable throughout the profile, the stickiness and plasticity varied ranging from slightly sticky and slightly plastic to sticky and plastic in the surface down to the subsurface horizons in both profiles. This could be due to the clay accumulation of the subsurface horizon. In Site 2, Ormoc Andisol GL, Ormoc Andisol FS, and Ormoc Andisol PF had loose to very friable soil which was slightly plastic and not plastic in the surface horizon. However, the subsurface horizons were very friable, non-sticky, and not plastic.

\section{Particle Size Analysis}

Soil texture refers to the variety of particle sizes in the soil whether wide or narrow and whether mainly large, small, or intermediate in size in a given soil volume (Hillel 2004). There were changes in soil texture among successional stages in Site 1 . Since there was a difference in soil development, Baybay Inceptisol PF had sandy loam texture in all horizons which pertains to underdeveloped horizons. On the other hand, Baybay Ultisol SF and Baybay Ultisol GL soil texture ranged from clay loam to clay in surface horizons and from clay to sandy clay loam in subsurface horizons. The clay accumulation in the subsurface horizon indicated a developed soil. Furthermore, in Site 2, Ormoc Andisol GL, Ormoc Andisol FS, and Ormoc Andisol PF had close ranges of soil texture from loam and sandy loam to loamy sand and sandy loam throughout the soil profile. Andisols are considered as young soils or underdeveloped soils (Figure 3 ). 


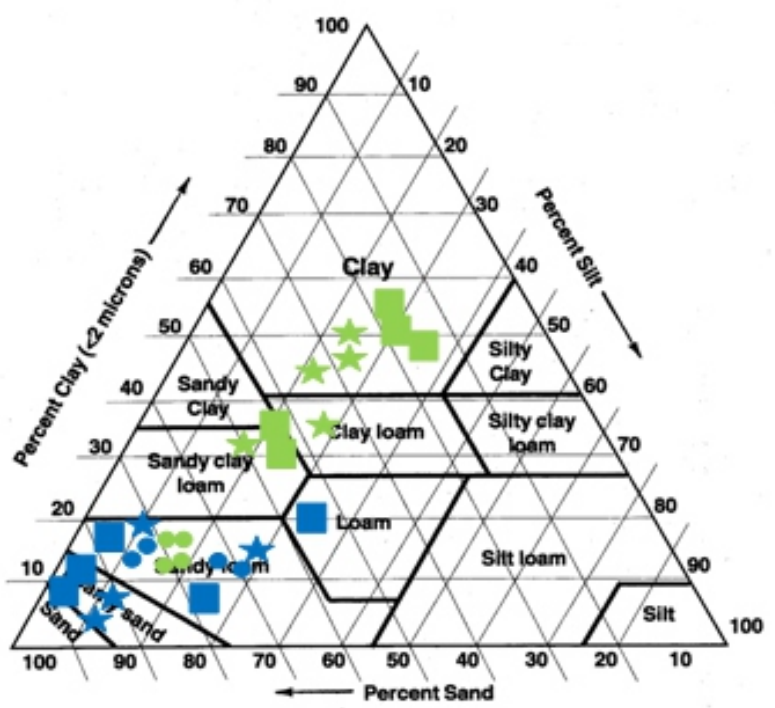

Legend:

Site 1 Site 2

Primary

Forest

Secondary

Forest

Grassland

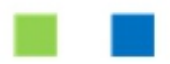

Figure 3. Particle size distribution of soils in different forest succession stages

\section{Bulk Density, Porosity, and Water Holding Capacity}

Bulk density is defined as the mass per unit volume of dry soils that includes both solid and voids volume, expressed in $\mathrm{g} \mathrm{cm}^{-3}$. Porosity is an indication of total volume of voids, expressed in percentage (\%) (Jahn et al 2006). Bulk density is affected by some factors such as soil texture and organic matter content (Schaetzl \& Anderson 2005). Bulk density values differed in both sites since these had different soil types. In Site 1, bulk density values ranged from $0.78-0.9 \mathrm{~g} \mathrm{~cm}^{-3}$ in the surface horizon to 0.82 $1.14 \mathrm{~g} \mathrm{~cm}^{-3}$ in the subsurface horizon of Baybay Inceptisol PF, Baybay Ultisol SF, and Baybay Ultisol GL. Baybay Inceptisol PF showed lower bulk density than Baybay Ultisol SF and Baybay Ultisol GL due to the development of the soil. Inceptisols are considered to be poorly developed soils compared with Ultisol. Soil texture plays a role in bulk density. Finer particles tend to increase the density of the soil, thus high clay content can increase the value of bulk density. All profiles in Site 2 had lower bulk density than those in Site 1. This ranged from $0.43 \mathrm{~g} \mathrm{~cm}^{-3}$ to $0.57 \mathrm{~g} \mathrm{~cm}^{-3}$ in the surface horizon and 0.44 $\mathrm{g} \mathrm{cm}^{-3}$ to $0.54 \mathrm{~g} \mathrm{~cm}^{-3}$ in the subsurface horizon (Figure $4 \mathrm{a}$ ). There was no difference in bulk density among the successional stages in Site 2. Soils from Site 2 were classified as Andisol, which often have lower bulk densities but higher porosity than other soil types because of high organic matter content, nanominerals, and well-developed aggregation (McDaniel et al 2012). Furthermore, values showed that bulk density in the subsurface horizon is higher than that in the surface horizon. This is due to organic matter accumulation in the surface where biological activity is high, which 
Changes in Soil Nitrogen, Phosphorus, and Carbon Stocks in a Forest Ecosystem creates pore spaces in the surface soils (Adams 1973; Alexander 1980). Soil porosity was inversely proportional to bulk density in all soil profiles in both sites. Therefore, Site 2 had higher porosity than that of Site 1 (Figure 4b). This can be explained by the soil texture, biological activities, and organic matter content, which improved soil aggregation.

Water holding capacity (WHC) is the state where the soil retains the maximum amount of water after the point of saturation. This is controlled by factors such as soil texture and organic matter content (Carter 2002; Brady $\&$ Weil 2014). Soil surface area is directly proportional to water holding capacity of the soil. Site 2 had higher WHC than Site 1, especially in Baybay Ultisol SF and Baybay Ultisol GL, despite having more clay content since Andisols can exceed $100 \%$ of WHC on a weight basis (Figure 4c). This is due to the presence of allophane, ferrihydrite, and metal-humus complexes, which contribute to high surface area (McDaniel et al 2012).
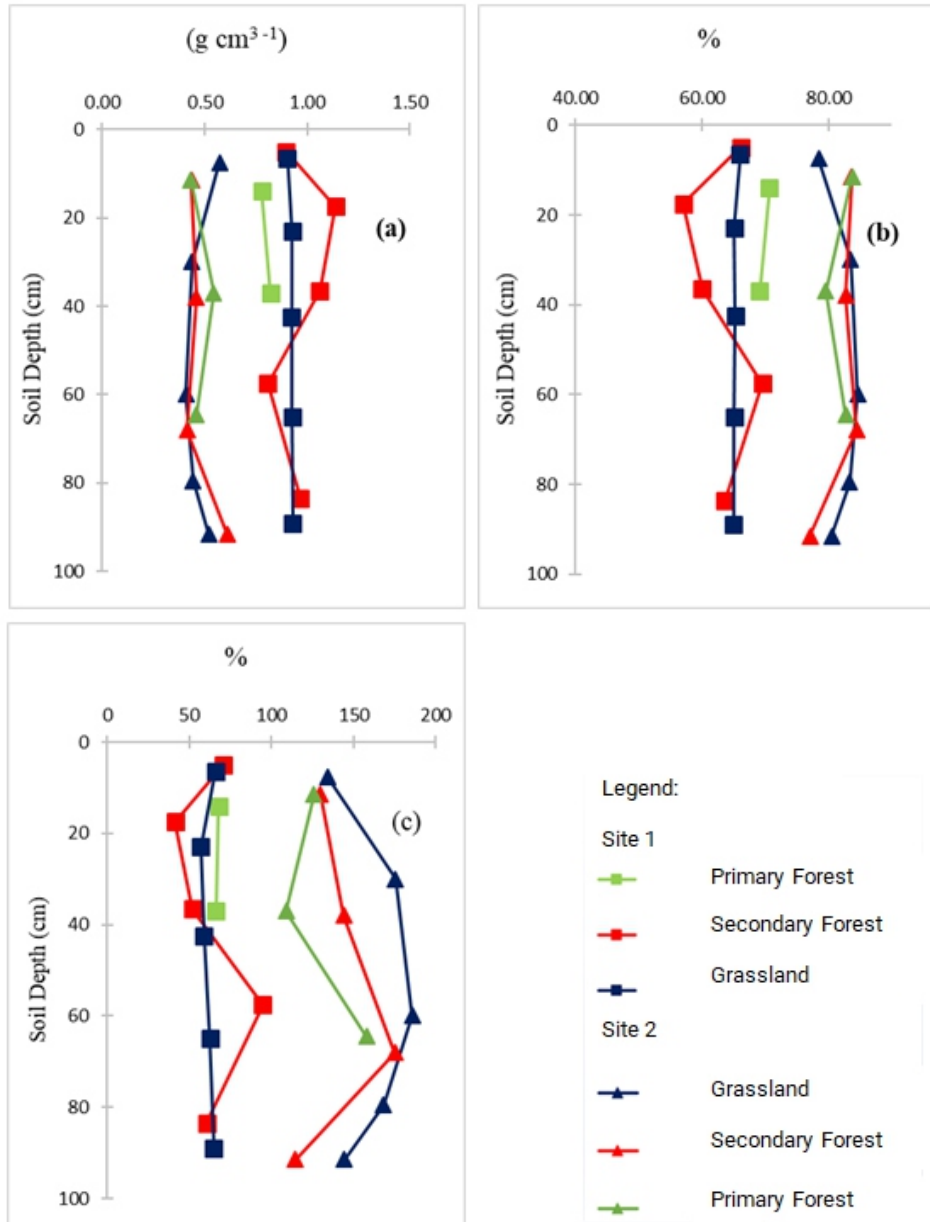

Figure 4. Depth function of (a) bulk density ( $\mathrm{g} \mathrm{cm}-3)$, (b) total porosity (\%) and (c) water holding capacity (\%) of soils derived from Sites 1 and 2 


\section{Soil pH}

Soil $\mathrm{pH}$ is the expression of the activity of hydrogen ions in the soil solution which affects the availability of mineral nutrients for plants as well as many soil processes (Jahn et al 2006). Figure $5(\mathrm{a} \& \mathrm{~b})$ shows $\mathrm{pH}_{\mathrm{H} 2 \mathrm{O}}$ and $\mathrm{KCl}$ of soils from different sites. Results showed that the soil $\mathrm{pH}_{\mathrm{H} 2 \mathrm{O}}$ of all profiles in Site 1 ranged from strongly acidic to slightly acidic (5.46-6.14) because Baybay Ultisol SF and Baybay Ultisol GL were considered more developed than Baybay Ultisol PF. All profiles from Site 2 ranged from strongly acidic to moderately acidic (5.42-5.59), according to Landon (1991). Generally, Site 2 was more acidic than Site 1 because according to the results of studies (Shoji et al 1993; Dahlgren et al 2004), Andisols are almost always acidic using water diluent ranging from 4.8-6.0. Upon subtracting $\mathrm{pH}_{\mathrm{KCl}}$ from $\mathrm{pH}_{\mathrm{H} 20}$, the result is the delta $\mathrm{pH}$ (Figure $5 \mathrm{c}$ ). Delta $\mathrm{pH}$ shows what the dominating charge in the soil is. In Site 1, all profiles had soil $\mathrm{pH}$ in $\mathrm{KCl}$ which was lower compared to $\mathrm{pH}$ in $\mathrm{H}_{2} \mathrm{O}$. This means that the soil colloids have negative charges. Thus, they have the capacity to hold more cations. While in Site 2, not all profiles were negatively charged. Ormoc Andisol SF and Ormoc Andisol PF contained positive charges at the lower horizons since Andisols exhibit anion exchange properties which are important for negatively charged nutrients such as $\mathrm{NO}^{3-}$ and $\mathrm{SO}_{4}{ }^{2-}$ (Shoji et al 1993).

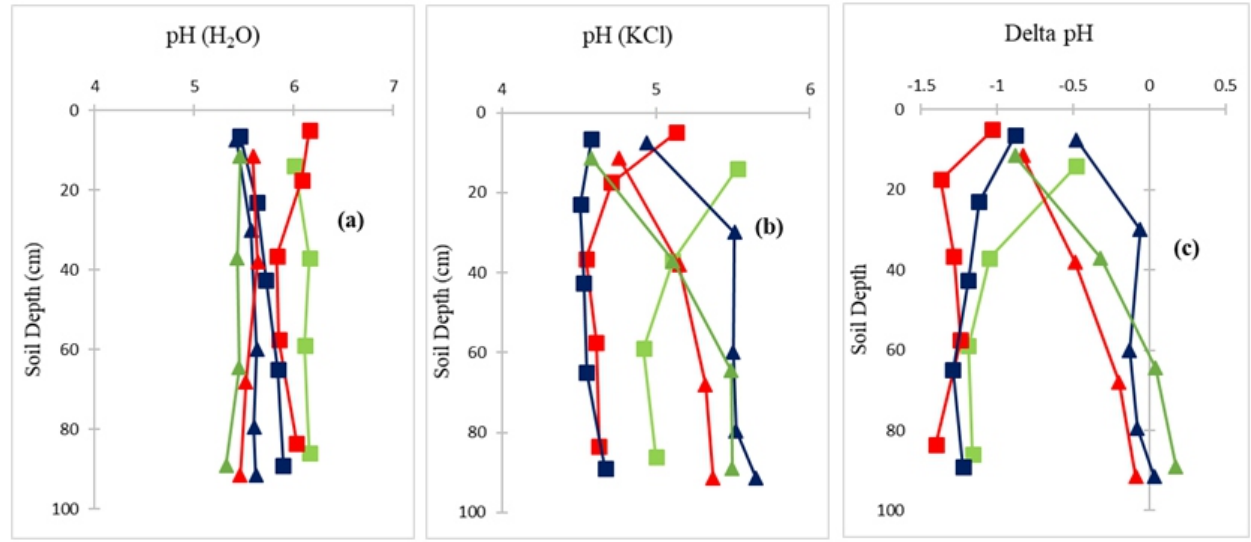

Legend:

Site 1

Site 2

$\begin{array}{llll}- & \text { Primary Forest } & - & \text { Grassland } \\ - & \text { Secondary Forest } & - & \text { Secondary Forest } \\ - & \text { Grassland } & - & \text { Primary Forest }\end{array}$

Figure 5. Depth function of (a) soil pH (H2O), (b) soil pH (KCl), and (c) delta $(\triangle) \mathrm{pH}$ of soils in Site 1 and Site 2 


\section{Soil Organic Matter}

Soil organic matter (SOM) refers to all decomposed, partly decomposed, and undecomposed organic material of plant and animal origin in the soil (Jahn et al 2006). Values revealed that SOM decreased as the depth increased in both sites (Figure 6a). In Site 1, SOM content in the surface horizon ranged from 5.8 to 11.7 percent, which is classified as medium to high (Landon 1991). Baybay Inceptisol PF contained the highest SOM content due to the large biomass of litter from the vegetation and the difficult terrain/steep slope of Mount Pangasugan that makes it less accessible resulting in lower disturbance. This was followed by Baybay Ultisol SF, and, lastly, Baybay Ultisol GL. Site 2 had the same trend with Ormoc Andisol PF, having the highest SOM content than the other successional stages. However, in Site 2, SOM content varied from 26.96 to 50.05 percent in the surface horizon which is considered to be very high (Landon 1991). It had greater SOM than that of Site 1. One common characteristic of an Andisol is that it can accumulate large quantities of organic matter in both allophanic and nonallophanic Andisols. Allophanic Andisol can contain 16-24\% SOM, whereas nonallophanic Andisol can contain up to 50-60\% SOM (Mizota \& van Reeuwijk 1989).

\section{Total Nitrogen}

Total nitrogen $(\mathrm{N})$ values in both sites showed that total $\mathrm{N}$ decreased as the depth increased, similar to the trend of SOM (Figure 6b). This is because organic matter plays a vital role in the soil as a source of $\mathrm{N}$ (Brady \& Weil 2014). Site 1 had total $N$ that ranged from 0.27 to 0.55 percent, that is medium to high. Baybay Inceptisol PF got the highest total $\mathrm{N}$ among all successions. In Site 2, total $\mathrm{N}$ ranged from 1.14 to 1.76 percent which is categorized by Landon (1991) as very high. Site 2 contained higher amounts of $\mathrm{N}$ than Site 1. This could be due to the net mineralization of $\mathrm{N}$ since it can be influenced by factors such as organic matter, texture, water content, soil structure, temperature, $\mathrm{pH}, \mathrm{C}: \mathrm{N}$ ratio of organic materials, and the presence of microorganisms in the soil (Carnice \& Lina 2017).

\section{Available Phosphorus}

Available phosphorus $(P)$ refers to the $P$ that is readily available to the plant. $P$ is essential for all living organisms. Plants must have phosphorus for normal growth and maturity. Figure $6 \mathrm{c}$ shows the available $P$ of different successions in Site 1 and Site 2. The available $P$ in all soil profiles, both in Sites 1 and 2, ranged from $0.81-1.16 \mathrm{~g} \mathrm{~kg}^{-1}$ at the surface horizon, which is classified as low by Landon (1991). Based on Landon's (1991) values, results showed the low availability of $\mathrm{P}$ among horizons in the soil profile in all 
successional stages in both sites. Both study sites were acidic because the phosphorus could have been fixed by $\mathrm{Al}$ and $\mathrm{Fe}$, making it unavailable for plant uptake. However, vegetation showed no evident signs of $P$ deficiency. This could be because the plants had adapted to this kind of environment or there is a possibility of mycorrhizal association in the vascular plants (Hawksworth 1992). Arbuscular mycorrhizal fungi (AMF) play an important role in plant nutrition by expanding the host plant's access to nutrients, especially P, while the host plant provides sugars and growth factors for the AMF (Koide \& Mosse 2004). This process is essential for the sustainability of the soil-plant system.
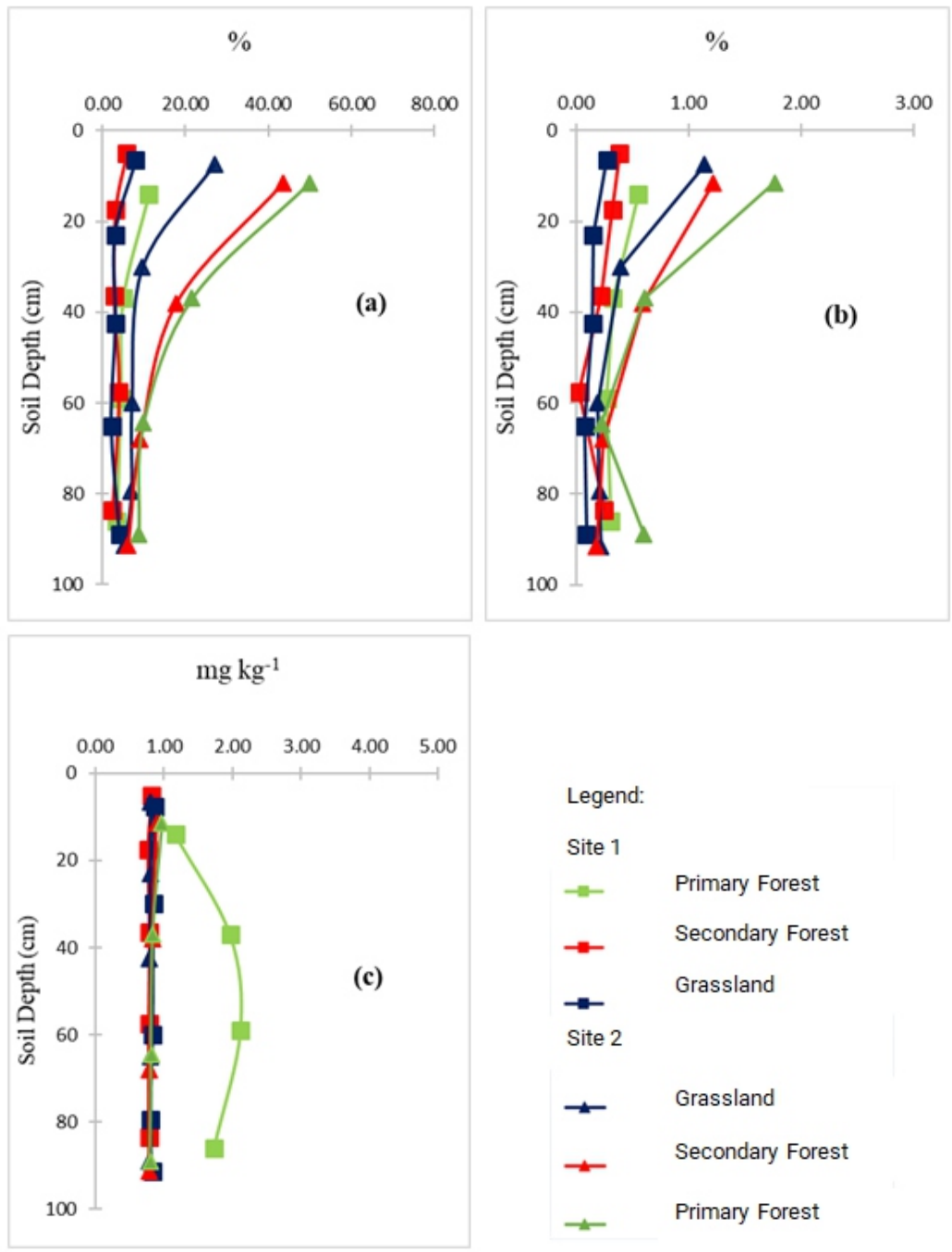

Figure 6. Depth function of (a) soil organic matter, (b) total nitrogen, and (c) available phosphorus of soils in Sites 1 and 2 


\section{Exchangeable Bases}

Exchangeable bases are defined as the alkali and alkaline earth metals: calcium ( $\mathrm{Ca}$ ), magnesium ( $\mathrm{Mg}$ ), potassium (K), and sodium $(\mathrm{Na})$, held by the negative charges of clay and organic constituents in the soils, which can be exchanged with each other and with other positively charged ions in the soil solution. Figure 7 shows the values of the exchangeable bases from the various profiles in Site 1 and Site 2. Generally, values of the exchangeable bases from all horizons of various profiles either in Site 1 or 2 were considered low (Landon 1991). However, in comparing the values from each site, Site 1 showed relatively higher values than those from Site 2, except on exchangeable $\mathrm{K}$ since the values from both sites followed the same trend. Low rates of exchangeable bases were caused by factors such as CEC, vegetation, and weathering of parent material. Low CEC means low exchange of basic cations and these cations are nutrients for plant use. Low weathering of parent material can cause shortage of cations in the soil solution. This results in the depletion of basic cations in the exchange sites.

Results showed that exchangeable $\mathrm{Mg}$ values were the highest compared to the other bases. Values ranged from 0.17 to $0.18 \mathrm{cmol} \mathrm{kg}^{-1}$ in Site 1, and varied from 0.02 to $0.07 \mathrm{cmol} \mathrm{kg}^{-1}$ in Site 2 (Figure 7d). Moreover, exchangeable Ca content ranged from 0.05 to $0.09 \mathrm{cmol} \mathrm{kg}^{-1}$ and 0.0018 to $0.0022 \mathrm{cmol} \mathrm{kg}^{-1}$ (Figure $7 \mathrm{~b}$ ). Exchangeable Na values varied from 0.018 $\mathrm{cmol} \mathrm{kg}^{-1}$ to $0.022 \mathrm{cmol} \mathrm{kg}^{-1}$ and from $0.011 \mathrm{cmol} \mathrm{kg}^{-1}$ to 0.028 and $\mathrm{cmol} \mathrm{kg}{ }^{-1}$ (Figure 7c). Lastly, exchangeable $\mathrm{K}$ values ranged from $0.03 \mathrm{cmol} \mathrm{kg}^{-1}$ to $0.04 \mathrm{cmol} \mathrm{kg}^{-1}$ and from $0.017 \mathrm{cmol} \mathrm{kg}^{-1}$ to $0.024 \mathrm{cmol} \mathrm{kg}^{-1}$ in the surface horizons from Site 1 and Site 2, respectively (Figure 7a).

\section{Cation Exchange Capacity}

Cation exchange capacity is the capacity of the soil to absorb or hold cations and be able to exchange cations. It is one of the important soil chemical properties which affects soil fertility. There are two types of CEC, namely: potential CEC ( $\left.\mathrm{CEC}_{\text {pot }}\right)$ and effective CEC $\left(\mathrm{CEC}_{\text {eff }}\right) . \mathrm{CEC}_{\mathrm{pot}}$ is the conventional $\mathrm{CEC}$ method (by $1 \mathrm{~N} \mathrm{NH}_{4} \mathrm{OAc}$ at $\mathrm{pH}$ 7.0) while the $\mathrm{CEC}_{\text {eff }}$ involves the summation of basic cations (extracted by $1 \mathrm{~N} \mathrm{NH}_{4} \mathrm{OAc}$ at $\mathrm{pH}$ 7.0) plus $1 \mathrm{M} \mathrm{KCl}$ exchangeable Al and acidity.

The $\mathrm{CEC}_{\text {pot }}$ of Site 1's surface horizon ranged from $30.51 \mathrm{cmol} \mathrm{kg}^{-1}$ to $34.59 \mathrm{cmol} \mathrm{kg}^{-1}$, while in Site 2 it was $32.36 \mathrm{cmol} \mathrm{kg}^{-1}$ to $48.70 \mathrm{cmol} \mathrm{kg}^{-1}$ (Figure 8a). These values in all soil profiles in both sites were considered high according to Landon (1991) except in Site 2 primary forest, which was classified as very high. $\mathrm{CEC}_{\mathrm{pot}}$ in Andisol is relatively high $\left(20-50 \mathrm{cmol} \mathrm{kg}^{-1}\right)$; however, it is mostly contributed by $\mathrm{pH}$ dependent charges. Since Andisols are mostly acidic, altering their $\mathrm{pH}$ could increase their CEC artificially (McDaniel et al 2012). On the other hand, Figure $8 \mathrm{~b}$ shows that $\mathrm{CEC}_{\text {eff }}$ in the 
surface horizons of Site 1 and Site 2 ranged from $0.47 \mathrm{cmol} \mathrm{kg}^{-1}$ to $0.58 \mathrm{cmol}$ $\mathrm{kg}^{-1}$, and from $0.53 \mathrm{cmol} \mathrm{kg}^{-1}$ to $1.76 \mathrm{cmol} \mathrm{kg}^{-1}$, respectively. In general, the $\mathrm{CEC}_{\text {eff }}$ rates were considered to be very low according to the criteria of Landon (1991). Low $\mathrm{CEC}_{\text {eff }}$ can limit the ability to retain and exchange $\mathrm{K}, \mathrm{Ca}$, $\mathrm{Na}$, and $\mathrm{Mg}$ in the soil.
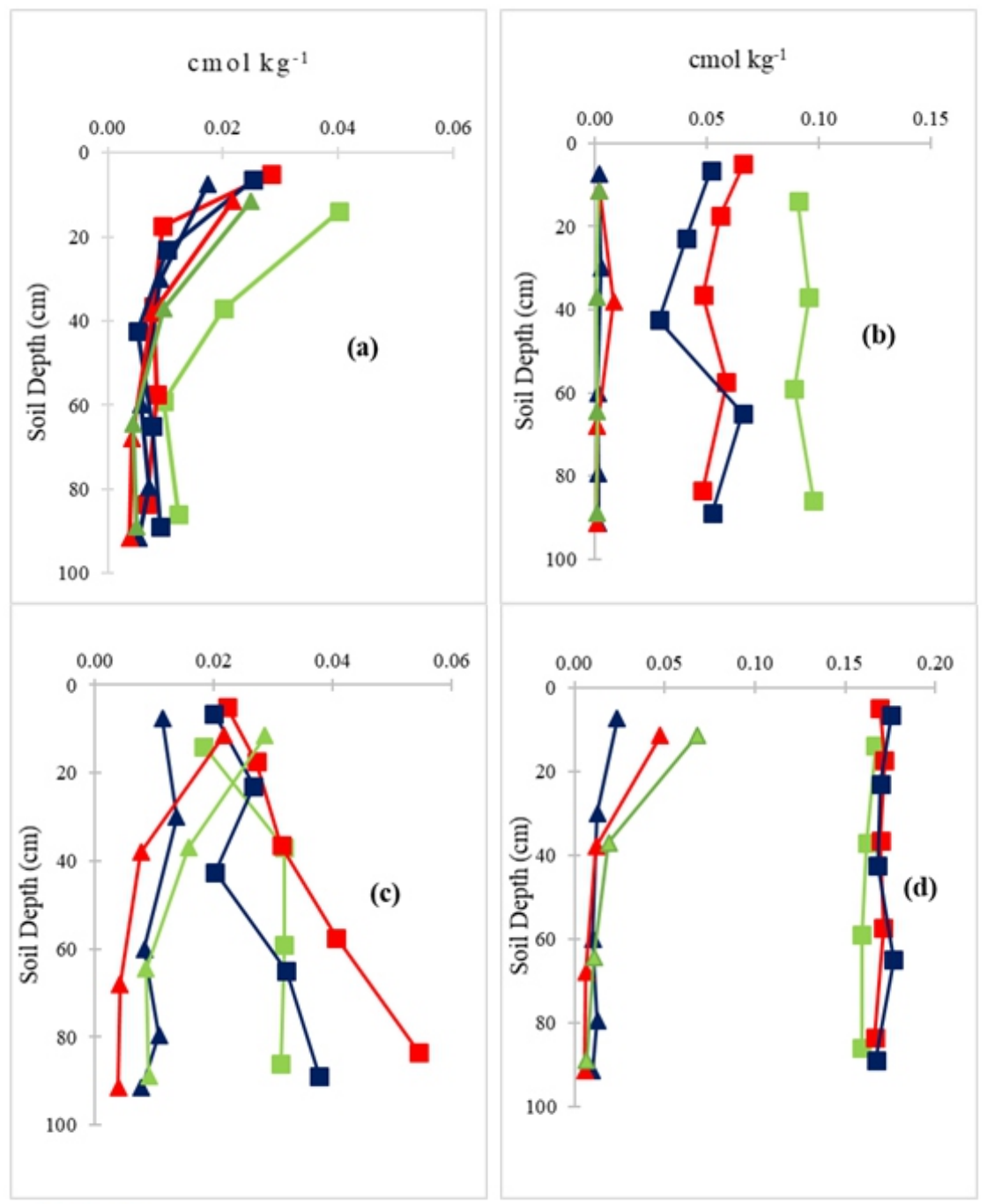

Legend:

Site 1

Site 2
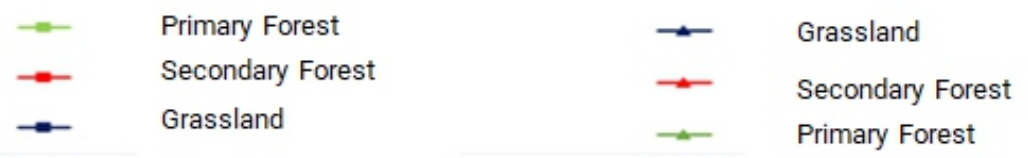

Figure 7. Depth function of (a) Exchangeable K, (b) Exchangeable Ca, (c) Exchangeable $\mathrm{Na}$, and (d) Exchangeable Mg of soils in Sites 1 and 2 


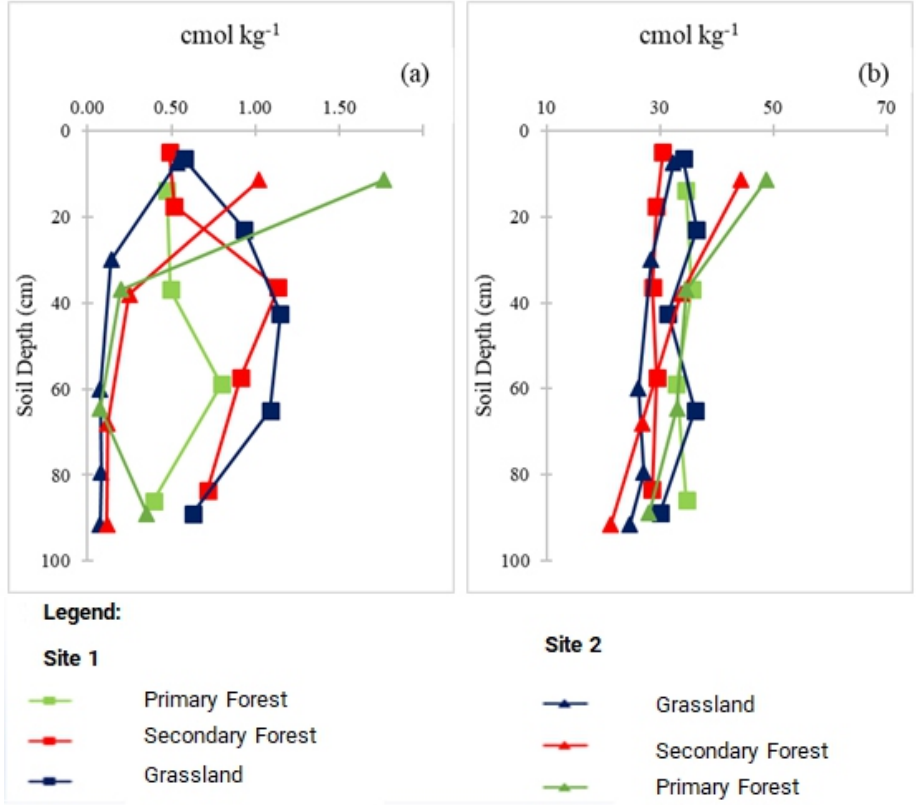

Figure 8. Depth function of (a) potential CEC and (b) effective CEC of soils in Sites 1 and 2

\section{Soil Carbon, Nitrogen and Phosphorus Concentration and Related Ratios}

Generally, the primary forests in both sites relatively contained higher concentrations of carbon $(C)$, nitrogen $(N)$, and phosphorus $(P)$ than the other forest succession stages. However, there was no significant difference in these concentrations among various forest succession stages in both sites except for available P in Site 1 and total $N$ in Site 2 (Figures 9a, 9b \& 9c). Comparing the area sampled, soils in Site 2 showed significantly higher values of total $\mathrm{C}$ and $\mathrm{N}$, but not available $\mathrm{P}$, than soils in Site 1. Soils in Site 2 naturally contained higher amounts of organic $C$ since these were Andisols. This coincided with the higher values of total $\mathrm{N}$ since organic matter is one of the major sources of $\mathrm{N}$ in the soil. All successional stages both in Site 1 and Site 2 had very low available P. Since soil P is highly sensitive to $\mathrm{pH}$, a decrease or increase of $\mathrm{pH}$ from neutral to nearly neutral can make $\mathrm{P}$ unavailable for plant use.

There was no significant difference in the $\mathrm{C}: \mathrm{N}$ ratio among the different successions in Site 1. Baybay Ultisol SF had the least value compared to Baybay Inceptisol PF and Baybay Ultisol GL. While in Site 2, there was a decreasing trend of $\mathrm{C}: \mathrm{N}$ ratio from Ormoc Andisol PF to Ormoc Andisol GL, but this had no significant difference (Figure 9d). In general, Ormoc Andisol $\mathrm{PF}$ had the highest $\mathrm{C}: \mathrm{N}$ ratio among all forest successions in both sites. Lower C: $\mathrm{N}$ ratio influences the $\mathrm{N}$ dynamics in the soil system. In this situation, there was nitrogen and carbon loss in all forest successions except for Ormoc Andisol PF. This favors rapid organic decomposition and 
nitrogen mineralization by the microorganisms in the soil (Mooshammer et al 2014). Furthermore, the $\mathrm{N}$ transformations are coupled with $\mathrm{C}$ transformations, where organic carbon molecules are converted into $\mathrm{CO}_{2}$ by the heterotroph microbial soil population (McGill et al 1975; McGill \& Cole 1981).

This explanation conforms to the result of the $\mathrm{CO}_{2}$ evolution of the soils from the various forest succession stages by substrate induced respiration. Figure 10 shows that Site 1 had higher $\mathrm{CO}_{2}$ evolution than Site 2. This suggests that the soil microorganisms in Site 1 were efficient in decomposing organic matter. In Site 2, the microbial decomposition rate may be restricted by Al toxicity and low pH values (IIImer et al 2003; Tate \& Theng 1980). Also, it can further be explained by the low C:N ratios of Site 1 since decomposition of organic matter in the soil depends on the $\mathrm{C}: \mathrm{N}$ ratios. The wider the $\mathrm{C}: \mathrm{N}$ ratio, the slower the rate of decomposition (Hättenschwiler et al 2011). Generally, as the span of incubation time increases, the $\mathrm{CO}_{2}$ evolution per hour decreases in all successions from both sites (Figures 10 a \& b). However, Baybay Inceptisol PF was the most responsive to the substrate while the Baybay Inceptisol SF showed the least response (Figure 10a). In Site 2, Ormoc Andisol SF was the most responsive while Ormoc Andisol PF showed the least reaction to the substrate (Figure 10b).

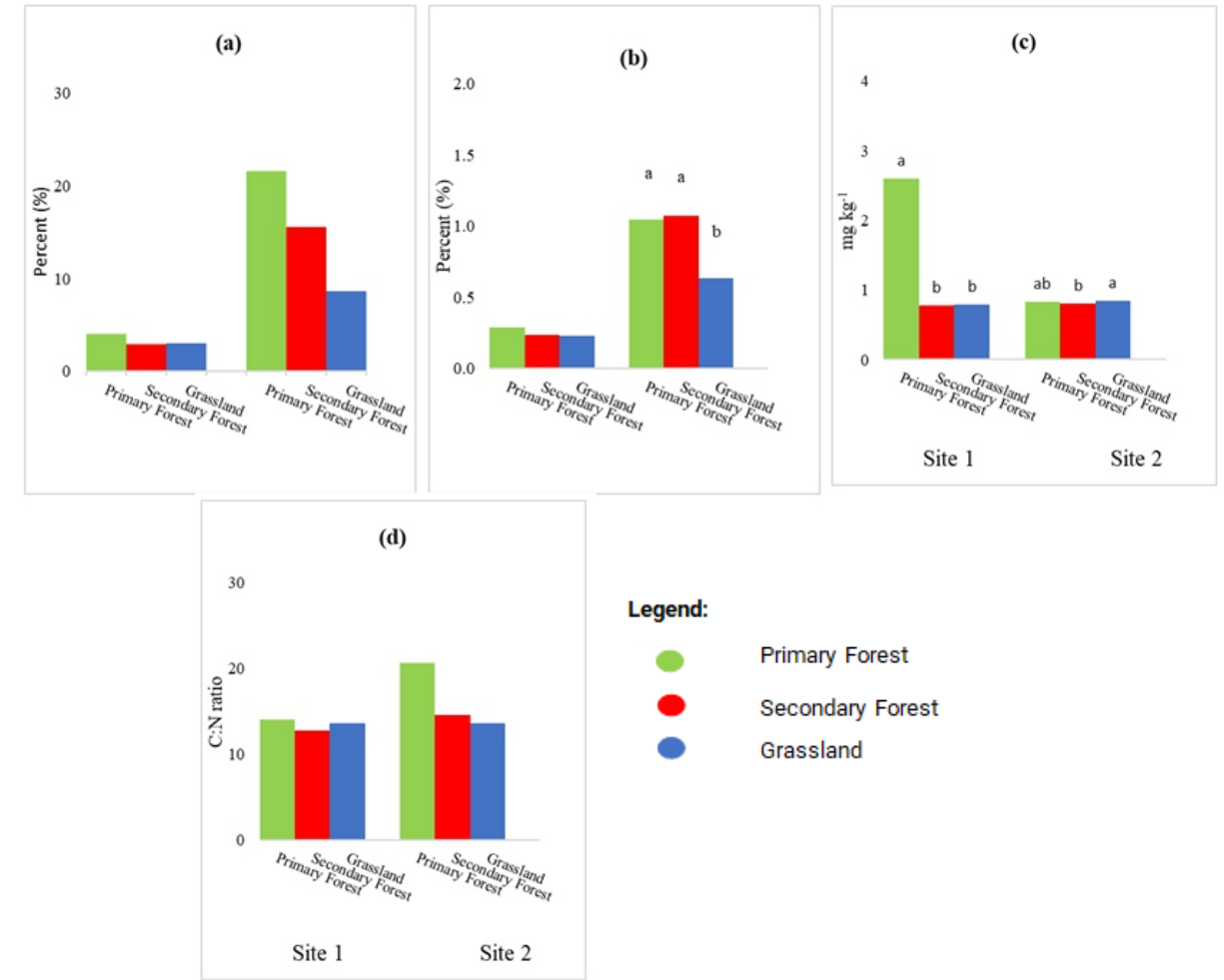

Figure 9. Means of (a) total carbon, (b) total nitrogen, (c) available phosphorus, and (d) C:N ratio of soils in Site 1 and Site 2 composite samples 


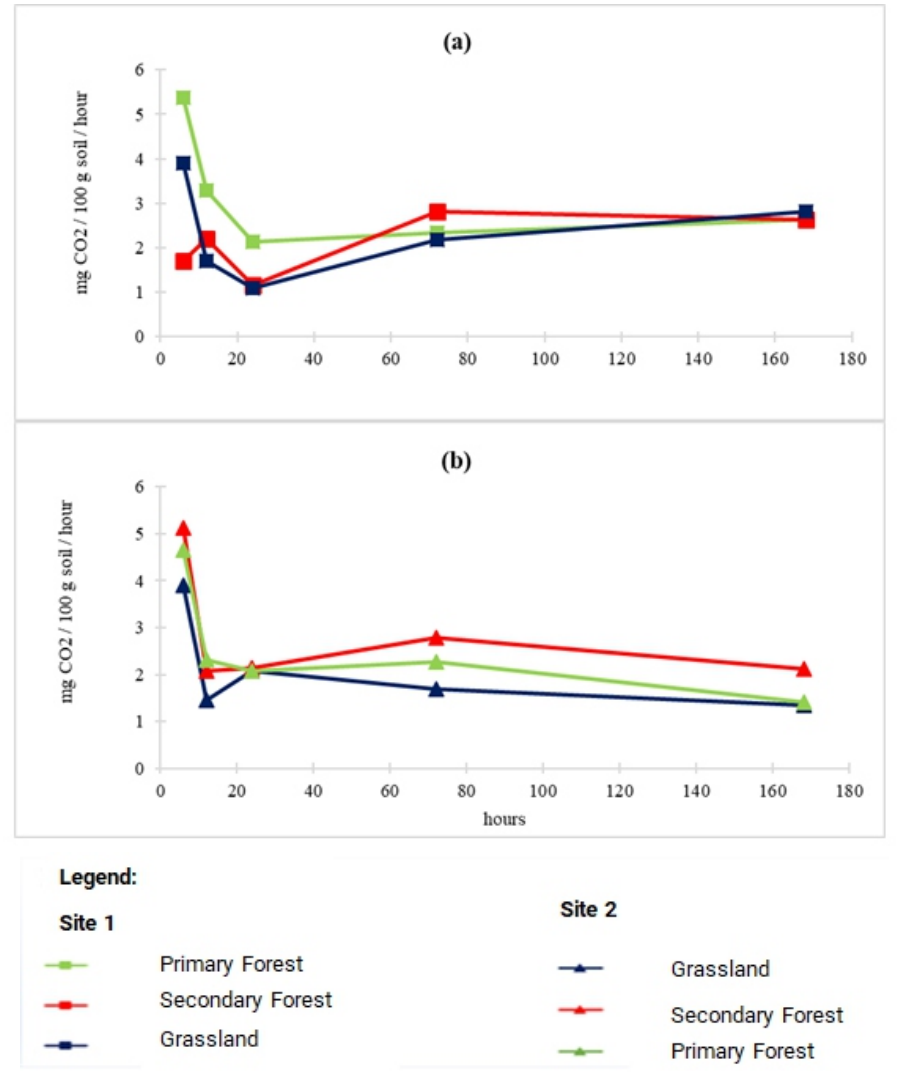

Figure 10. Substrate induced respiration of soils composite samples in (a) Site 1 and (b) Site 2

\section{Soil Organic Carbon Stocks Assessment}

Evaluating soil organic carbon (SOC) stocks is needed in assessing the potential for carbon (C) sequestration of soils of different types from various forest succession stages. According to Lal (2004), C sequestration is a process of converting the atmospheric $\mathrm{C}$ into the soil through time from the organic residues of plants in a form that is not readily available for emission.

The SOC stocks were in decreasing from the primary forest, secondary to the grassland specifically in Site 2 but the difference was not significant. Baybay Ultisol SF showed the least value of SOC stocks. This could be due to less litter input from the young vegetation in the area due to previous deforestation. On the other hand, SOC stocks in Site 2 had a decreasing trend from Ormoc Andisol PF down to Ormoc Andisol GL. Site 2 had higher SOC stocks than Site 1 (Figure 11). Ormoc Andisol PF stored $180 \mathrm{Mg} \mathrm{C} \mathrm{ha}^{-1}$, while Baybay Inceptisol PF contained only $76 \mathrm{Mg} \mathrm{C} \mathrm{ha}^{-1}$. Ormoc Andisol SF stored $133 \mathrm{Mg} \mathrm{C} \mathrm{ha}^{-1}$, while Baybay Ultisol SF contained $49 \mathrm{Mg} \mathrm{C} \mathrm{ha}^{-1}$. Lastly, 
Ormoc Andisol GL contained $108 \mathrm{Mg} \mathrm{C} \mathrm{ha}^{-1}$, while Baybay Ultisol GL only stored $55 \mathrm{Mg} \mathrm{C} \mathrm{ha}^{-1}$. Thus, soils in Cabintan, Ormoc City, Leyte (Andisols) were more effective in sequestering $C$ than soils in Pangasugan, Baybay City, Leyte (Ultisol). This can be explained by the unique soil morphophysicochemical properties attributing to the composition of its mineralogy. The soil minerals consist of allophane, imogolite, ferrihydrite, and Al- and Fe-humus complexes (Harsh et al 2002). At lower $\mathrm{pH}$, the formation of $\mathrm{Al}$ - and Fe- complexes will be favored. In addition, the high SOC stocks in Andisols is the function of the high surface areas of noncrystalline minerals (allophane and imogolite) which are available for the sorption of organic matter (Baldock \& Nelson 2000; Saggar et al 1994). This intimate interaction of organic matter and non-crystalline minerals can increase the stability of organic matter against decomposition where humification dominates over mineralization (Baldock \& Skjemstad 2000; Mikutta et al 2006; Sollins et al 1996; Torn et al 1997). Furthermore, Parfitt (2009) found that the residence time of $C$ in Andisols is much greater than that in other soil orders.

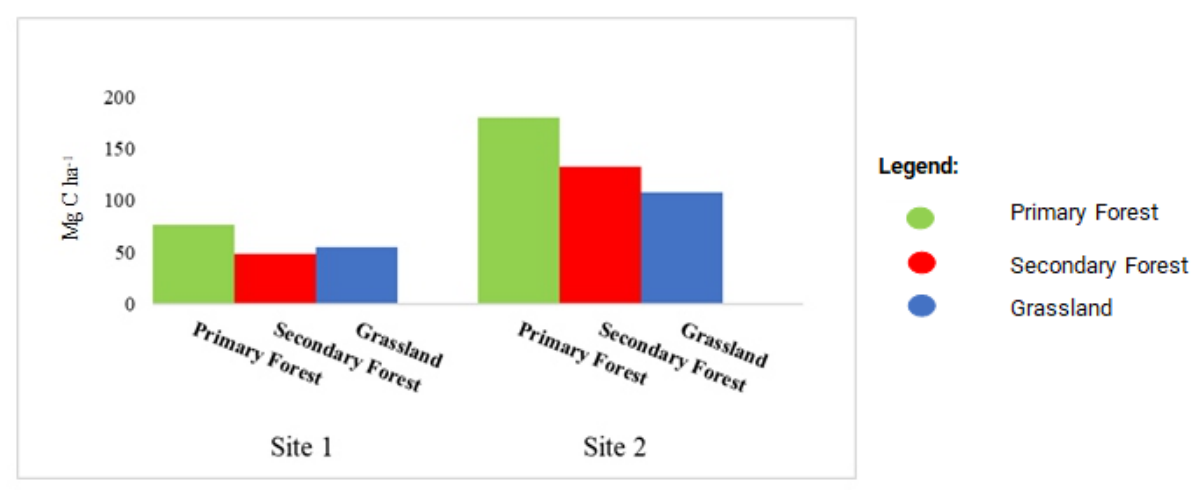

Figure 11. Soil organic carbon stocks of soils in Site 1 and Site 2 composite samples

\section{CONCLUSIONS AND RECOMMENDATIONS}

\section{Conclusions}

Based on the results of the study, the following conclusions can be drawn:

1. There is a decreasing trend of soil organic carbon stocks upon conversion from primary forest to secondary forest and grassland which is more pronounced in Site 2. Thus, land use conversion can cause the increase of $\mathrm{CO}_{2}$ in the atmosphere.

2. $\mathrm{C}: \mathrm{N}$ ratios in all forest succession stages in Site 2 were relatively higher 
than in Site 1. Therefore, losses of $\mathrm{C}$ in soil is dominant in Site 1 through the action of microbial decomposition.

3. Soil physicochemical characteristics influenced SOC stocks in Site 1 and Site 2. Andisols had higher potential in storing organic $\mathrm{C}$ than Ultisols.

\section{Recommendations}

Agricultural activities should be regulated, especially in Site 2 (Ormoc), where decreasing SOC stocks were observed from primary forest to grassland. It is also suggested that a similar area be studied looking into the above ground biomass and the litterfall in different forest successions. Also, it is worthwhile to look into the biological properties of the soil such as microbial biomass and $\mathrm{CO}_{2}$ evolution, since the vegetation and litterfall dictates the influx of $\mathrm{C}$ while biological activities show the outflux of $\mathrm{C}$. Furthermore, assessment on the indigenous arbuscular mycorrhizal fungi in the area is necessary in order to assess how these plant species survive in $\mathrm{P}$ deficient soil environment.

\section{ACKNOWLEDGMENT}

The authors are thankful to the Department of Science and Technology (DOST) Accelerated Science and Technology Human Resource Program National Science Consortium (ASTHRDP-NSC) for the financial and scholarship support, particularly to the first author. Thanks are also accorded to the Department of Soil Science, Visayas State University for supporting the conduct of this study. The author is also thankful to the following members of his Graduate Advisory Committee for their comments and suggestions on the thesis manuscript: Dr. Romel B. Armecin (Soil Science) and Dr. Marlito M. Bande (Tropical Ecology).

\section{REFERENCES}

Adams WA. 1973. The effect of organic matter on the bulk and tree densities of some uncultivated podzolic soils. J. Soil Sci. 24:10-17.

Allen EB, Violi HA, Allen MF \& Go'Mez-Pompa A. 2003. Restoration of tropical seasonal forest in Quintana Roo. pages 587-598 in A. Go'mezPompa, M. F. Allen, S. L. Fedick, and J. Jimenez-Osornio, editors. The lowland Maya area: three millenia at the human-wildland interface. Haworth Press, Binghamton, New York, USA.

Alexander EB. 1980. Bulk densities of California soils in relation to other soil properties. Soil Sci. Soc. Am. J. 44: 689-692.

Asio VB. 1996. Characteristics, weathering, formation, and degradation of soils from volcanic rocks in Leyte, Philippines. Hohenheimer Bodenkundliche Hefte, Vol. 33, Stuttgart, Germany. 
Baethgen WE and Alley MM. 1989. A manual colorimetric procedure for measuring ammonium nitrogen in soil and plant Kjeldahl digests. Communications in Soil Science and Plant Analysis 20: 961-969.

Baldock JA and Nelson PN. 2000. Soil organic matter. In: Sumner, M. (Ed.), Handbook of Soil Science. CRC Press, Boca Raton, FL, pp. B25-B84.

Baldock JA and Skjemstad JO. 2000. Role of the soil matrix and minerals in protecting natural organic materials against biological attack. Organic Geochemistry 31, 697-710. doi:10.1016/S01466380(00)00049-8

Brady NC and Weil RR. 2014. The Nature and Properties of Soils. 14th ed. Pearson Prentice Hall, US A. 1046 pp.

Carter MR. 2002. Soil quality for sustainable land management: organic matter and aggregation interactions that maintain soil functions. Agron. J. 94:38-47.

Carnice PAB and Lina Sb. 2017. Carbon Storage and Nutrient Stocks Distribution of Three Adjacent Land Use Patterns in Lake Danao National Park, Ormoc, Leyte, Philippines. Journal of Science, Engineering and Technology 5:1-14.

Coronas J. 1920. The climate and weather of the Philippines. 1903-1918. Bureau of Print. Manila. $189 \mathrm{pp}$.

De Koning GHJ, Veldkamp E \& Lopez-Ulloa M. 2003. Quantification of carbon sequestration in soils following pasture to forest conversion in northwestern Ecuador. Global biogeochemical Cycles, 17(4), 1098.

Dela Cruz L, Abanto R and Tulod A. 2008. Carbon sequestration potentials of tree species in a degraded pasture in Mt. Makiling. Paper presented at FOREPI Conference. PCARRD.

Dela Cruz L. 2010. Harnessing the carbon sequestration potential of forest soils strategies for climate mitigation and adoption. Guillermo Ponce Professorial chair lecture. College, Laguna, UPLB.

Dahlgren RA, Saigusa M \& Ugolini FC. 2004. The nature, properties, and management of volcanic soils. Advances in Agronomy 82: 113-182.

Hawksworth DL. 1991. The fungal dimension of biodiversity: magnitude, significance, and conservation. Mycological Research. 95, 641-655.

Hansen MC, Potapov PV, Moore R, Hancher M, Turubanova SA, Tyukavina A \& Kommareddy A. 2013. High-resolution global maps of 21st-century forest cover change. Science, 342(6160): 850-853.

Harsh JB, Chorover J \& Nizeyimana E. 2002. Allophane and immogilite. In: Dixon, J.B., Schulze, D.G. (Eds.), Soil mineralogy with environmental applications. Book Series No. 7. Soil Science Society of A m e r i c a, Madison, pp. 291-321.

Hättenschwiler S, Coq S, Barantal S \& Handa IT. 2011. Leaf traits and decomposition in tropical 5 rainforests: revisiting some commonly held views and towards a new hypothesis, New Phytol., 189, 950-965, doi:10.1111/j.1469-8137.2010.03483.x. 
Heanes DL. 1984. Determination of total organic-C in soils by an improved chromic acid digestion and spectrophotometric procedure. Commun. Soil Sci. Plant Anal. 15: 1191-1213.

Hillel D. 2004. Introduction to Environmental Soil Physics. Elsevier Science, USA.

Illmer P, Obertegger U \& Schinner F. 2003. Microbiological properties in acidic forest soils with special consideration of $\mathrm{KCl}$ extractable Al. Water Air Soil Pollut. 148, 3-14.

International Soil Reference and Information Center (ISRIC). 1995. Procedures for soil analysis (L.P. Van Reuwijk, Editor). Wageningen, the Netherlands. 106.pp.

ISRIC. 2002. Procedures for soil analysis (L.P. Van Reuwijk, Editor). Wageningen, the Netherlands. Technical Paper No. 9.

Jahn R, Blume HP, Asio VB, Spaargaren O \& Schad P. 2006. Guidelines for soil description. 4th edition. FAO of the United Nations, Rome.

Klute A. 1986. Water retention: laboratory methods. In A. Klute (ed.) Methods of Soil Analysis, Part 1, Physical and Mineralogical Methods, Agronomy Monograph no. 9, 2nd edition. Madison, WI, American Soil Association and Soil Science Society of America, pp. 635-662.

Koide RT and Mosse B. 2004. A history of research on arbuscular mycorrhiza. Mycorrhiza 14, 145-163.

Landon JR. 1991. Booker Tropical Soil Manual. Longman Scientific and Technical, Essex, England. 474 pp.

Lasco RD, Pulhin FB \& Cruz RVO. 2007. Carbon stock assessment of forest land uses in the Kaliwa Watershed, Philippines. Journal of environmental science and management, 10 (2): 40-48.

Mcdaniel PA, Lowe DJ, Arnalds O \& Ping CL. 2012. Andisols. In: Huwang, P.M., Li, Y., Sumner, M.E. (editors) "Handbook of Soil Science. 2nd edition. Vol. 1, Properties and Processes.' CRC Press (Taylor and Francis), Boca Raton, FL, pp. 33.29-33.48

Mcgill WB and Cole CV. 1981. Comparative aspects of cycling of organic C, N, S and P through soil organic matter, Geoderma, 26, 267-286.

Mcgill WB, Shields JA \& Paul EA. 1975. Relation between carbon and nitrogen turnover in soil organic fractions of microbial origin, Soil Biol. Biochem. 7, 57-63.

Meyfroidt P and Lambin EF. 2011. Global forest transition: prospects for an end to deforestation. Annual Review of Environment and Resources, 36: 343-371.

Mikutta R, Kleber M, Torn MS \& Jahn R. 2006. Stabilization of soil organic matter: association with minerals or chemical recalcitrance? Biogeochemistry 77,25-56. doi:10.1007/s10533-005-0712-6

Mizota C and Van Reeuwijk LP. 1989. Clay mineralogy and chemistry of soils formed in volcanic materials in diverse climatic regions. International Soil Reference and Information Centre Monograph 2:1-185. 
Mooshammer M, Wanek W, Hämmerle I, Fuchslueger L, Hofhansl F, Knoltsch A, Schnecker J, Takriti M, Watzka M, Wild B, Keiblinger KM, Zechmeister Boltenstern S \& Richter A. 2014. Adjustment of microbial nitrogen use efficiency to carbon:nitrogen imbalances regulates soil nitrogen cycling, Nat. Commun., 5. 3694.

Parfitt RL. 2009. Allophane and imogolite: role in soil biogeochemical processes. Clay Minerals 44:135-155.

Paul S, Flessa H, Veldkamp E \& Lopez-Ulloa M. 2008. Stabilization of recent soil carbon in the humid tropics following land use changes: evidence from aggregate fractionation and stable isotope analyses. Biogeochemistry. 87, 247-263.

PCARR. 1980. Standard methods for soil, plant tissue, water and fertilizer.

Farm and System res. Div. Philippine Council for Agriculture and Resources Research, Los Baños. 164 pp.

Reed ST and Martens DC. 1996. Copper and Zinc. In D.L Sparks (Editor-inChief), Soil Science Society of America, Book Series 5. Method of Soil Analysis Part 3, Chemical methods. Madison, Wisconsin: Soil Science Society of America, Inc.

Salang ED. 2010. Carbon sequestration by Faraon and Adtuyon soils under different cropping and tillage system in Zamboanga Peninsula.

Saggar S, Tate KR, Feltham CW, Childs CW \& Parshotam A. 1994. Carbon turnover in a range of allophanic soils amended with 14C-labelled glucose. Soil Biol. Biochem. 26, 1263-1271.

Schaetzal R and Anderson S. 2005. Soils: Genesis and Geomorphology. Cambridge Univ. Press, New York, USA. 817 pp.

Schlichting E, Blume HP \& Stahr K. 1995. Bodenkundliche Praktikum (Soil Science Practicum). (2nd ed.) Blackwell, Berlin.

Secretariat of The Convention On Biological Diversity. 2001. The Value of Forest Ecosystems. Montreal, SCBD, 67p. (CBD Technical Series no. 4).

Shoji S, Nanzyo M \& Dahigren RA. 1993. Volcanic ash soils: Genesis, properties and utilization. Developments in soil science 21: 1-288.

Soil Survey Staff. 1999. Soil Taxonomy: A Basic System of Soil Classification for Making and Interpreting Soil Surveys. (2nd ed.). UDSANRCS, Washington, DC.

Sollins P, Homann P \& Caldwell BA. 1996. Stabilization and destabilization of soil organic matter: mechanisms and controls. Geoderma 74, 65105.

Tate KR and Theng BKG. 1980. Organic matter and its interactions with inorganic soil constituents. In: Theng, B.K.G. (Ed.), Soils with Variable Charge. Offset Publications, Palmerstone North, pp. 225-249.

Thomas GW. 1982. Exchangeable cations, pp. 159-165. In C.A. Black, ed. Methods of Soil Analysis, Part II. Chemical and Microbiological Properties. $2^{\text {nd }}$ Edition. Agronomy No. 9. ASA and SSSA Inc., Madison, WI.

Torn MS, Trumbore SE, Chadwick OA, Vitousek PM \& Hendricks DM. 1997. 
Changes in Soil Nitrogen, Phosphorus, and Carbon Stocks in a Forest Ecosystem

Mineral control of soil organic carbon storage and turnover. Nature 389, 170-173. doi:10.1038/38260

Veldkamp E, Becker A, Schwendenmann L, Clark DA \& Schulte Bisping H. 2003. Substantial labile carbon stocks and microbial activity in deeply weathered soils below a tropical wet forest. Global Change Biol. 9, 11711184. 